\title{
Childhood cancer in the Northern Region, 1968-82: incidence in small geographical areas
}

\author{
A W CRAFT, S OPENSHAW, AND J M BIRCH \\ From the Departments of Child Health and Geography, University of Newcastle upon Tyne, and Children's \\ Tumour Registry, University of Manchester
}

SUMMARY The place of residence of all cases of childhood cancer occurring in the Northern Region from 1968 to 1982 has been analysed by electoral wards. The wards have been ranked according to rate and Poisson probability. Both rankings show a wide geographical scatter throughout the region of areas with an apparent excess incidence of cancer. These areas are not confined to the Cumbrian coast.

There has been considerable correspondence and publicity following a Yorkshire Television programme transmitted in November 1983 in which it was alleged that there was an increased rate of cancer in young people living in villages close to the Sellafield nuclear reprocessing plant in Cumbria. The government have responded to this by setting up an enquiry committee under the chairmanship of $\mathrm{Sir}$ Douglas Black. ${ }^{1}$ The Northern and North Western Regions of England both have children's cancer registries run on an identical basis and achieving a high degree of completeness and accuracy with regard to the totality of patients registered and the quality of data on each case. ${ }^{2}$ The overall incidence of childhood cancer in the two regions is virtually identical, that is, $\mathbf{9 9 \cdot 3}$ per million total population for the Manchester registry ${ }^{3}$ and 106 for the Newcastle based registry. ${ }^{4}$ Data relating to the incidence of childhood malignancy in the north of England, subdivided into county and local authority areas, has failed to show any significant increase in any area studied or to show any trends towards increasing incidence with time. ${ }^{5}$ However, it is possible that an increased incidence for more localised areas might have been missed by the previous analysis so that we have now reanalysed our data by very small geographical areas.

\section{Methods}

All children diagnosed as having cancer before their 15 th birthday who were resident in the Northern Region at the time of diagnosis have been included in the study. The data studied here are mainly those collected by the Newcastle registry but do include patients from South West Cumbria who, before the
1974 National Health Service reorganisation, were in the North West Region and exclude all patients from North Yorkshire who, before 1974, were included in the Northern Region. The diagnosis and address at the time of diagnosis were recorded. Each address was assigned a postcode using the standard British Telecom directories. These were then converted into a $100 \mathrm{~m}$ point reference by SIA Ltd, London, who provide a commercial postcode to grid-reference service.

The region was subdivided into 675 census wards. These are small administrative areas for which accurate population data are available from census returns. Each child's address was then allocated to the appropriate 1981 census ward using a "point in polygon" procedure. Accurate population data are available from the 1981 census, and these were used to calculate cancer rates for each of the wards. The wards were then ranked according to (a) the incidence rate, that is, the number of cases per 1981 child population, and (b) a cumulative Poisson probability index. ${ }^{6}$

\section{Results}

Data from 1113 patients have been analysed for the period 1968-82. We do not yet have comprehensive data on 1983 cases. Tables 1 to 3 show the number of cancers, child population, the Poisson probability, the rate per 1000 children, and the ratio of the ward to the average regional incidence for the top 25 wards, ranked in order of Poisson probability, for all cancers, all lymphoid malignancies, that is, acute lymphoblastic leukaemia + Hodgkin's disease + non Hodgkin's lymphoma, and all brain tumours. Figures 
Table 1 All cancers 1968-82

\begin{tabular}{|c|c|c|c|c|c|c|}
\hline Ward & $\begin{array}{l}\text { Rank } \\
\text { order }\end{array}$ & $\begin{array}{l}\text { No. } \\
\text { cancers }\end{array}$ & $\begin{array}{l}\text { Child } \\
\text { population }\end{array}$ & $\begin{array}{l}\text { Poisson } \\
\text { probability }\end{array}$ & $\begin{array}{l}\text { Rate per } \\
1000 \\
\text { children }\end{array}$ & $\begin{array}{l}\text { Ratio } \\
\text { ward/regional } \\
\text { incidence }\end{array}$ \\
\hline Monkseaton W, T\&W & 1 & 8 & 953 & 0.0003 & $8 \cdot 39$ & $4 \cdot 79$ \\
\hline Prudhoe S, Tynedale, NLD & 2 & 6 & 676 & 0.0014 & $8 \cdot 87$ & $5 \cdot 07$ \\
\hline Easterside, Cleveland & 3 & 7 & 1021 & 0.0024 & $6 \cdot 85$ & 3.91 \\
\hline Wampool, Allerdale, Cumbria & 4 & 5 & 605 & 0.0046 & $8 \cdot 26$ & $4 \cdot 72$ \\
\hline Seascale, Copeland, Cumbria & 5 & 4 & 411 & 0.0063 & $9 \cdot 73$ & $5 \cdot 56$ \\
\hline Seaton Delaval, NLD & 6 & 5 & 657 & 0.0065 & $7 \cdot 61$ & $4 \cdot 34$ \\
\hline Framwellgate Moor, Durham & 7 & 5 & 662 & 0.0067 & $7 \cdot 55$ & $4 \cdot 31$ \\
\hline Elsdon, Alnwick, NLD & 8 & 2 & 97 & 0.0129 & $20 \cdot 61$ & $11 \cdot 78$ \\
\hline Barrow Island, Cumbria & 9 & 5 & 780 & 0.0129 & 6.41 & 3.66 \\
\hline Kendal Underley, Cumbria & 10 & 3 & 281 & 0.0138 & $10 \cdot 67$ & $6 \cdot 10$ \\
\hline Winlaton, T\&W & 11 & 9 & 2161 & 0.0156 & $4 \cdot 16$ & $2 \cdot 38$ \\
\hline Dawdon, Easington, Durham & 12 & 7 & 1463 & 0.0159 & $4 \cdot 78$ & $2 \cdot 73$ \\
\hline Saltburn, Cleveland & 13 & 6 & 1138 & 0.0163 & $5 \cdot 27$ & 3.01 \\
\hline Carlisle 7, Cumbria & 14 & 6 & 1154 & 0.0173 & $5 \cdot 19$ & $2 \cdot 97$ \\
\hline Gateshead 16, T\&W & 15 & 9 & 2312 & 0.0228 & $3 \cdot 89$ & $2 \cdot 22$ \\
\hline Newcastle St. Anthonys, T\&W & 16 & 6 & 1272 & 0.0262 & $4 \cdot 71$ & 2.69 \\
\hline Whittingham, NLD & 17 & 2 & 133 & 0.0269 & $13 \cdot 88$ & $7 \cdot 93$ \\
\hline Ennerdale, Copeland, Cumbria & 18 & 3 & 374 & 0.0288 & $8 \cdot 02$ & $4 \cdot 58$ \\
\hline Warden \& Newbrough, NLD & 19 & 2 & 165 & 0.0345 & $12 \cdot 12$ & 6.92 \\
\hline Chesters, Tynedale, NLD & 20 & 2 & 183 & 0.0415 & $10 \cdot 92$ & $6 \cdot 24$ \\
\hline Marsh, Allerdale, Cumbria & 21 & 3 & 440 & 0.0432 & $6 \cdot 81$ & $3 \cdot 89$ \\
\hline South Tyneside 3, T\&W & 22 & 4 & 749 & 0.0442 & $5 \cdot 34$ & 3.05 \\
\hline Gateshead $7, T \& W$ & 23 & 5 & 1090 & 0.0447 & $4 \cdot 58$ & $2 \cdot 62$ \\
\hline Gilesgate Moor, Durham & 24 & 4 & 802 & 0.0541 & 4.98 & $2 \cdot 85$ \\
\hline North Tyneside 2, T\&W & 25 & 9 & 2749 & 0.0564 & $3 \cdot 27$ & 1.87 \\
\hline
\end{tabular}

T\&W $=$ Tyne \& Wear

NLD $=$ Northumberland

Table 2 All lymphoid malignancies 1968-82

\begin{tabular}{|c|c|c|c|c|c|c|}
\hline Ward & $\begin{array}{l}\text { Rank } \\
\text { order }\end{array}$ & $\begin{array}{l}\text { No. } \\
\text { cancers }\end{array}$ & $\begin{array}{l}\text { Child } \\
\text { population }\end{array}$ & $\begin{array}{l}\text { Poisson } \\
\text { probability }\end{array}$ & $\begin{array}{l}\text { Rate per } \\
1000 \\
\text { children }\end{array}$ & $\begin{array}{l}\text { Ratio } \\
\text { ward/regional } \\
\text { incidence }\end{array}$ \\
\hline Seascale, Copeland, Cumbria & 1 & 4 & 411 & 0.0001 & $9 \cdot 73$ & $15 \cdot 99$ \\
\hline Fairfield, Stockton, Cleveland & 2 & 4 & 976 & 0.0032 & 4.09 & $6 \cdot 73$ \\
\hline Whittingham, NLD & 3 & 2 & 144 & 0.0036 & $13 \cdot 88$ & $22 \cdot 82$ \\
\hline Sedgefield 1, Durham & 4 & 4 & 1207 & 0.0068 & $3 \cdot 31$ & $5 \cdot 44$ \\
\hline North Ormesby, Cleveland & 5 & 4 & 1353 & 0.0100 & 2.95 & $4 \cdot 85$ \\
\hline Ayresome, Cleveland & 6 & 4 & 1632 & 0.0186 & 2.45 & $4 \cdot 02$ \\
\hline Fens, Hartlepool, Cleveland & 7 & 4 & 1890 & 0.0296 & $2 \cdot 11$ & $3 \cdot 47$ \\
\hline Sunderland $23, T \& W$ & 8 & 4 & 1942 & 0.0322 & $2 \cdot 05$ & $3 \cdot 38$ \\
\hline Saltburn, Cleveland & 9 & 3 & 1138 & 0.0332 & $2 \cdot 63$ & $4 \cdot 33$ \\
\hline Newburn No. $1, T \& W$ & 10 & 4 & 1971 & 0.0337 & 2.02 & $3 \cdot 33$ \\
\hline Beechwood, Cleveland & 11 & 3 & 1155 & 0.0345 & $2 \cdot 59$ & $4 \cdot 26$ \\
\hline Wear Valley 3, Durham & 12 & 3 & 1191 & 0.0372 & $2 \cdot 51$ & $4 \cdot 13$ \\
\hline Sedbergh, Cumbria & 13 & 2 & 514 & 0.0398 & $3 \cdot 89$ & $6 \cdot 39$ \\
\hline Consett N, Durham & 14 & 2 & 523 & 0.0411 & $3 \cdot 82$ & $6 \cdot 28$ \\
\hline North Tyneside 16, T\&W & 15 & 3 & 1261 & 0.0428 & $2 \cdot 37$ & 3.91 \\
\hline South Tyneside $19, \mathrm{~T} \& \mathrm{~W}$ & 16 & 3 & 1268 & 0.0434 & $2 \cdot 36$ & $3 \cdot 88$ \\
\hline Mirehouse E, C/land, Cumbria & 17 & 2 & 549 & 0.0448 & 3.64 & $5 \cdot 98$ \\
\hline Egglescliffe, Cleveland & 18 & 4 & 2226 & 0.0487 & $1 \cdot 79$ & 2.95 \\
\hline Sedgefield 12, Durham & 19 & 2 & 582 & 0.0497 & 3.43 & $5 \cdot 64$ \\
\hline Gateshead $16, T \& W$ & 20 & 4 & 2312 & 0.0545 & 1.73 & $2 \cdot 84$ \\
\hline Annfield Plain, Durham & 21 & 2 & 621 & 0.0557 & $3 \cdot 22$ & $5 \cdot 29$ \\
\hline Elsdon, Alnwick, NLD & 22 & 1 & 97 & 0.0573 & $10 \cdot 30$ & 16.94 \\
\hline Wear Valley 13, Durham & 23 & 2 & 639 & 0.0586 & $3 \cdot 12$ & $5 \cdot 14$ \\
\hline North Tyneside $8, T \& W$ & 24 & 3 & 1444 & 0.0594 & $2 \cdot 07$ & $3 \cdot 41$ \\
\hline North Tyneside $12, \mathrm{~T} \& \mathrm{~W}$ & 25 & 3 & 1446 & 0.0596 & 2.07 & $3 \cdot 40$ \\
\hline
\end{tabular}

$T \& W=$ Tyne $\&$ Wear

NLD $=$ Northumberland 
Table 3 All brain tumours 1968-82

\begin{tabular}{|c|c|c|c|c|c|c|}
\hline Ward & $\begin{array}{l}\text { Rank } \\
\text { order }\end{array}$ & $\begin{array}{l}\text { No. } \\
\text { cancers }\end{array}$ & $\begin{array}{l}\text { Child } \\
\text { population }\end{array}$ & $\begin{array}{l}\text { Poisson } \\
\text { probability }\end{array}$ & $\begin{array}{l}\text { Rate per } \\
1000 \\
\text { children }\end{array}$ & $\begin{array}{l}\text { Ratio } \\
\text { ward/regional } \\
\text { incidence }\end{array}$ \\
\hline Barrow Island, Cumbria & 1 & 4 & 780 & 0.0001 & $5 \cdot 12$ & $15 \cdot 60$ \\
\hline Bedlington W, NLD & 2 & 3 & 799 & 0.0025 & $3 \cdot 75$ & $11 \cdot 42$ \\
\hline Endmoor, Cumbria & 3 & 2 & 479 & 0.0112 & $4 \cdot 17$ & $12 \cdot 70$ \\
\hline North Tyneside 5, T\&W & 4 & 3 & 1513 & 0.0142 & 1.98 & $6 \cdot 03$ \\
\hline Wampool, Allerdale, Cumbria & 5 & 2 & 605 & 0.0173 & $3 \cdot 30$ & 10.05 \\
\hline Wear Valley 1, Durham & 6 & 2 & 655 & 0.0201 & 3.05 & $9 \cdot 29$ \\
\hline Prudhoe S, Tynedale, NLD & 7 & 2 & 676 & 0.0213 & $2 \cdot 95$ & $9 \cdot 00$ \\
\hline Wheatley Hill, Durham & 8 & 2 & 727 & 0.0244 & $2 \cdot 75$ & $8 \cdot 37$ \\
\hline Gilesgate Moor, Durham & 9 & 2 & 802 & 0.0292 & $2 \cdot 49$ & $7 \cdot 58$ \\
\hline St. John's, Cumbria & 10 & 2 & 821 & 0.0305 & $2 \cdot 43$ & $7 \cdot 41$ \\
\hline Elsdon, Alnwick, NLD & 11 & 1 & 97 & 0.0313 & $10 \cdot 30$ & $31 \cdot 37$ \\
\hline Park, Middlesbrough, Cleveland & 12 & 2 & 857 & 0.0329 & $2 \cdot 33$ & $7 \cdot 10$ \\
\hline Horden S, Easington, Durham & 13 & 2 & 858 & 0.0330 & $2 \cdot 33$ & $7 \cdot 09$ \\
\hline North Tyneside $15, T \& W$ & 14 & 2 & 953 & 0.0399 & $2 \cdot 09$ & $6 \cdot 38$ \\
\hline Newburn $2, \mathrm{~T} \& \mathrm{~W}$ & 15 & 4 & 4057 & $0 \cdot 0465$ & 0.98 & $3 \cdot 00$ \\
\hline North Tyneside $21, T \& W$ & 16 & 3 & 2481 & 0.0497 & $1 \cdot 20$ & 3.68 \\
\hline Central, Barrow, Cumbria & 17 & 2 & 1100 & 0.0515 & $1 \cdot 81$ & $5 \cdot 53$ \\
\hline Gateshead 9, T\&W & 18 & 4 & 4257 & 0.0536 & 0.93 & $2 \cdot 85$ \\
\hline Hawkshead, Cumbria & 19 & 1 & 168 & 0.0537 & $5 \cdot 95$ & $18 \cdot 11$ \\
\hline Saltburn, Cleveland & 20 & 2 & 1138 & 0.0547 & $1 \cdot 75$ & $5 \cdot 34$ \\
\hline Carlisle 7, Cumbria & 21 & 2 & 1154 & 0.0561 & $1 \cdot 73$ & $5 \cdot 27$ \\
\hline Redesdale, NLD & 22 & 1 & 183 & 0.0584 & $5 \cdot 46$ & $16 \cdot 62$ \\
\hline Chesters, Tynedale, NLD & 23 & 1 & 183 & 0.0584 & $5 \cdot 46$ & $16 \cdot 62$ \\
\hline Murton E, Easington, Durham & 24 & 2 & 1227 & 0.0624 & 1.62 & 4.96 \\
\hline Belford, Berwick, NLD & 25 & 1 & 201 & 0.0639 & $4 \cdot 97$ & $15 \cdot 13$ \\
\hline
\end{tabular}

$\mathrm{T} \& \mathrm{~W}=$ Tyne $\&$ Wear

NLD $=$ Northumberland

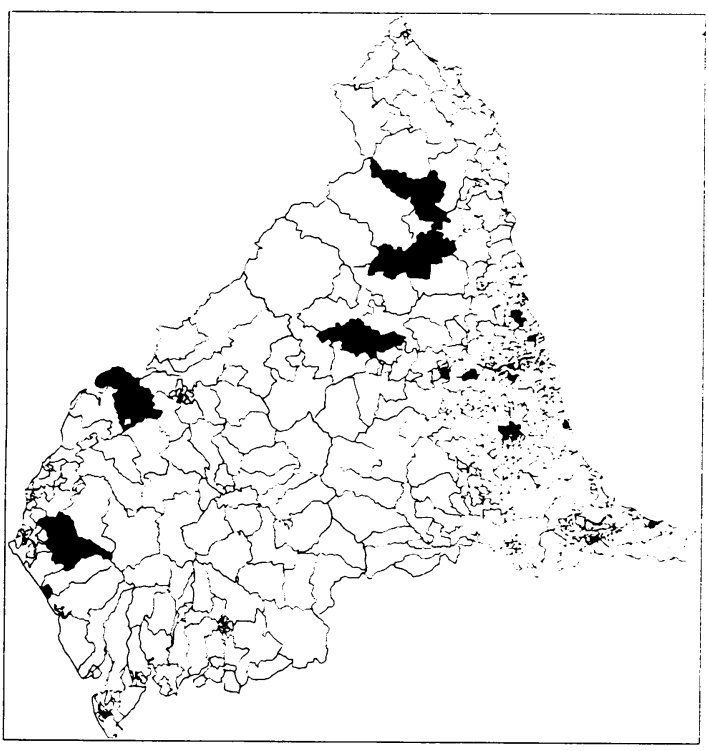

Fig 1 All cancer: wards with Poisson probability $p<0.05$.

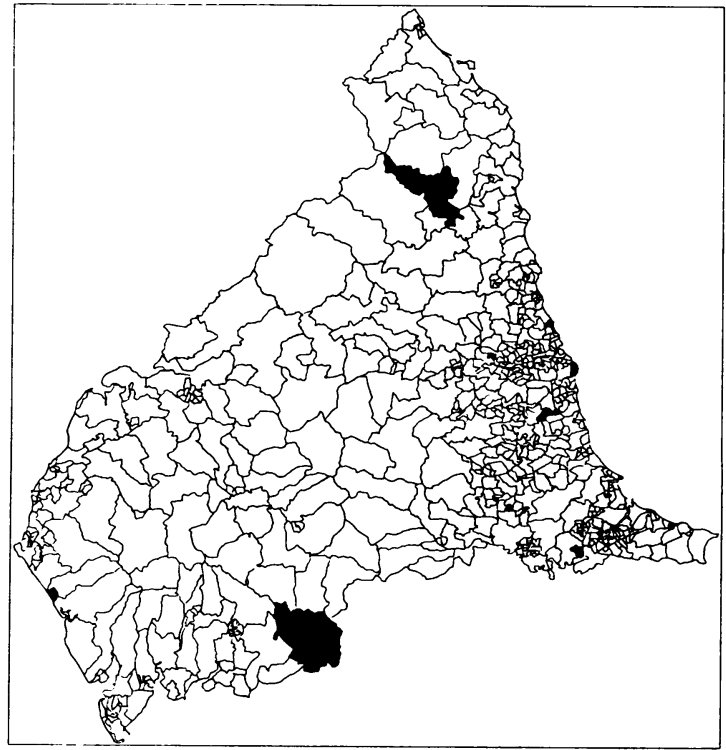

Fig 2 All lymphoid malignancy: wards with Poisson probability $p<0.05$. 


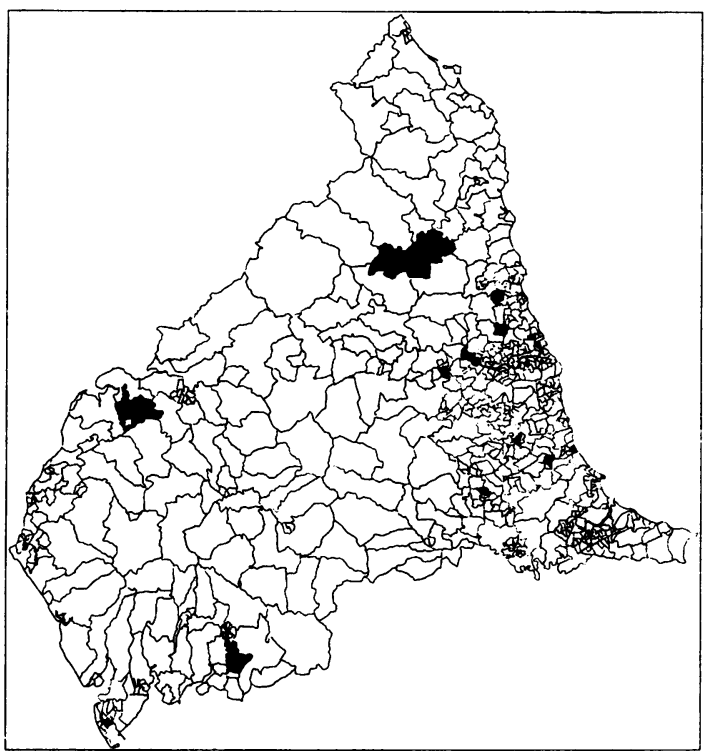

Fig 3 Brain tumours: wards with Poisson probability $p<0.05$.

wards, ranked highly by Poisson probability, for each of the disease categories. The size of the shaded areas on the maps reflects only the geographical size of the ward concerned.

\section{Discussion}

The analysis of the incidence data has been carried out using the 1981 census data for total childhood population. There is clearly a source of error here in that the population of children has undoubtedly changed over the past 15 years. However, the purpose of this paper is to demonstrate the breadth of the variation in incidence which is possible when considering very small areas. It is felt that this would not be materially altered by changes in population that may have taken place, although the rank order of the wards may change. Further work is in hand using the 1971 and 1981 census tracts.

Seascale, which ranks first by Poisson probability for all lymphoid malignancies, is the village closest to the Sellafield nuclear reprocessing plant. However, it is by no means unique as the only ward with an apparently excessive rate of childhood malignancy. The others, as can be seen from the figures, are scattered throughout the region. The excess is not confined to coastal areas of Cumbria. The highest rate of lymphoid malignancy is in Whittingham, a village in North Northumberland, where there were two children with leukaemia out of a total childhood population of only 144 , this being 31 times the regional incidence. For all childhood cancers the ward with the highest incidence is Elsdon, a village in Northumberland, $w$ hile that ranked first by the Poisson probability statistic is Monkseaton, part of an urban area of North Tyneside on the Northumberland coast. For brain tumours, the second most common malignancy in childhood, there is a similar scatter of "highly ranked" areas throughout the region.

Reports of clusters of leukaemias and lymphomas in the literature have been numerous but the significance of these isolated clusters cannot be evaluated. ${ }^{7}$ With rare diseases such as leukaemias and lymphomas some clustering will occur by chance. In 1968, in an analysis of the significance of leukaemia clusters, ${ }^{8}$ it was concluded that "seemingly high concentrations of cases could be generated by overzealous statistical manipulation". From the present data it can be seen that many small areas of the Northern Region could be claimed to have an excessive rate of childhood cancer. Equally, there are areas with an exceptionally low incidence. These variations in distribution are almost certain to occur in a group of diseases with an average incidence of 106 per million total population.

At present we know of no aetiological factor that could account for the apparent excess of cases in Seascale and other villages throughout the Northern Region. The dose of radiation to which the population of Cumbria is apparently exposed, including normal background radiation, ${ }^{9}$ is well within prescribed safety limits and is less than normal background radiation levels in other parts of Great Britain. There is no recognised association between the level of background radiation and the incidence of childhood cancer, and comparisons between leukaemia incidence at all ages in areas with different levels of background radiation have failed to demonstrate any correlation. ${ }^{10}$

The Black Committee ${ }^{1}$ concluded that although there did appear to be an excess of cancer in young people in Seascale and the surrounding Millom Rural District, this could not be accounted for by exposure to environmental radiation. They urged further geographical analysis using more accurate population data and also looking at age specific incidence rates. It is hoped that further work along these lines can be performed and an analysis carried out on data from the other registries to determine whether the spread of variation in incidence rates is similar.

Further studies to search for aetiological factors are also indicated, and this may be aided by identifying areas with an apparent high incidence and then looking for common environmental factors in these areas. 
The Newcastle registry was supported by the Cancer Research Campaign, Tyneside Leukaemia Research Association and the North of England Children's Cancer Research Fund. The Manchester registry is supported by the Cancer Research Campaign. Mr Martin Charlton assisted with the computer graphics.

\section{References}

${ }^{1}$ Black D. Investigation of the possible increased incidence of cancer in Cumbria. London: HMSO, 1984.

${ }^{2}$ Birch JM, Marsden HB, Swindell R. Incidence of malignant disease in childhood: a 24-year review of the Manchester Children's Tumour Registry data. $\mathrm{Br} J$ Cancer 1980; 42: 215-23.

${ }^{3}$ Birch JM. Epidemiology of paediatric cancer. In: Duncan W. ed: Paediatric oncology. Berlin: Springer-Verlag, 1983. Ch. 1.
${ }^{4}$ Craft AW, Long D. Childhood cancer in the Northern Region 1968-1982. Arch Dis Child (Abstract), in press.

${ }^{5} \mathrm{Craft}$ AW, Birch JM. Childhood cancer in Cumbria. Lancet 1983; i: 1299.

${ }^{6}$ White RR. Probability maps of leukaemia mortality in England and Wales. In: McGlashan ND, ed: Medical geography. London, Methuen: 1972.

${ }^{7}$ Smith PG. Spatial and temporal clustering. In: Schottenfeld D, Fraumeni JF Jr, eds: Cancer epidemiology and prevention. Philadelphia: Saunders, 1982, Ch.21.

${ }^{8}$ Glass AG, Hill JA, Miller RW. Significance of leukemia clusters. J Pediatr 1968; 73: 101-7.

${ }^{9}$ Hunt GJ. Aquatic environment monitoring report, No. 9. Radioactivity in surface and coastal waters of the British Isles. Ministry of Agriculture, Fisheries and Foods, 1981.

${ }^{10}$ Court-Brown WM, Spiers FW, Doll R, et al. Geographical variation in leukaemia mortality in relation to background radiation and other factors. $B r$ Med J, 1960; 1: 1753-9. 